\title{
Impact of climate variability and streamflow alteration on groundwater contribution to the base flow of the Lower Zab River (Iran and Iraq)
}

\author{
Ruqayah Mohammed ${ }^{1} \cdot$ Miklas Scholz $^{2}$
}

Received: 9 February 2016/ Accepted: 14 October 2016/Published online: 25 October 2016

(C) The Author(s) 2016. This article is published with open access at Springerlink.com

\begin{abstract}
Overall water resources evaluations including groundwater contributions to river flow are critical for assessing climate change and drought impacts on basin hydrological responses. By utilising precipitation, daily stream flow and simulated river discharge alteration data, this study introduces a simple but comprehensive methodology to better understand the potential impact of river regulation coupled with climate variability and drought on groundwater involvement. The Lower Zab River basin in northern Iraq has been selected as a representative case study to demonstrate the new methodology. Three of the most commonly used base flow separation methods were assessed: Eckhardt algorithm, flow duration curve and Chapman filtering algorithm. In addition, the indicators of hydrologic alteration method and the reconnaissance drought index have been applied. The results demonstrated that some of the underground water responds to precipitation events. A noticeable increase in groundwater contribution has been observed during the hydrological years between 1998-2001 and 2006-2008 as a result of a sharp decline in the average precipitation. However, the opposite has been observed during the hydrological year 1987, which impacted negatively on the basin water resources availability. The reservoir release through the dry periods causes the observed
\end{abstract}

Miklas Scholz

miklas.scholz@tvrl.lth.se

1 Civil Engineering Research Group, School of Computing, Science and Engineering, The University of Salford, Newton Building, Peel Park Campus, Salford, Greater Manchester M5 4WT, UK

2 Division of Water Resources Engineering, Department of Building and Environmental Technology, Faculty of Engineering, Lund University, P.O. Box 118, 22100 Lund, Sweden variations in base flow index (BFI) values between the preand post-river damming time periods. Considering the BFI long-term seasonal variation, index values started to rise in April and reached their maximum by the end of June. A steady decline has been recorded between August and September.

Keywords Climatology · Environmental assessment . Groundwater contamination and vulnerability . Hydrogeology · Surface water - Water management

\section{Introduction}

\section{Background}

Separation of streamflow hydrographs into dry-weather or base flow and direct run-off components is a useful technique to understand the groundwater contribution to rivers, in particular, when concerned with a varied range of water resources organisation matters (Brodie and Hostetler 2005; $\mathrm{Lu}$ et al. 2015). Such techniques also have been utilised to quantify the groundwater element of hydrological budgets and to assist in the estimation of recharge rates. The direct run-off component represents the additional streamflow contributed by sub-surface flow and surface flow, whereas the base flow component represents steady groundwater flow contributions to river discharge. Brodie and Hostetler (2005) argued that the exploration of groundwater inputs to watercourses is important when discussing matters such as the water resources supply probability of failure, water distribution and design of water storages, hydroelectric power generation and water needs for ecosystems.

Various techniques have been developed to isolate the base flow from the overall run-off hydrograph, which is 
traditionally categorised into three basic techniques: graphical base flow isolation, filtering algorithms frequency analysis and recession analysis (Brodie and Hostetler 2005; WMO 2009; Welderufael and Woyessa 2010). Tallaksen and van Lannen (2004) pointed out that Nathan and McMahon (1990) distinguished between methods for continuous separation regarding different components of flow.

Graphical methods separate the base flow component on a discharge hydrograph by connecting an intersection point of base flow and direct flow upon the hydrograph rising limb lowest flow point to a point on the falling limb where it is assumed all flows are changed to base flow (Linsley et al. 1988; Welderufael and Woyessa 2010). These techniques partition base flow in different ways that vary in their complexity and involve the constant flowrate, constant slope and concave technique (Brodie and Hostetler 2005). Conversely, Lim et al. (2005) confirmed that the main drawback of these techniques is that they do not provide consistent outcomes even with similar flow data.

The filtering techniques are the most regularly used methods in river flow separation, which splits the base flow by a filtering or processing procedure (Eckhardt 2005; Lim et al. 2005, 2010; Welderufael and Woyessa 2010). These methods have been recommended for providing reproducible results, can easily be automated, and should be linked to the base flow react of a river basin (Arnold et al. 2000; Eckhardt 2005). For the purpose of this paper, two of the recursive digital filtering techniques have been used: the Eckhardt (2005) and Chapman (1999) methods. The latter is one of the most commonly used recursive filtering algorithms for base flow separation.

The frequency duration or flow duration curve method represents the relationship between the magnitude and the frequency of daily, weekly or monthly discharges for a specific river watershed (Cigizoglu and Bayazit 2000). It is another widespread approach to analyse the characteristics of a river and used to estimate the time percentage the stream discharge is equal or exceed a historical period (Welderufael and Woyessa 2010). If the contributions of groundwater are minor, the curve slope at the lower end tends to be steep, whereas a flat curve indicates significant base flow.

A number of indices can be provided by flow duration curves to describe the streamflow rating or regionalisation purposes. If the flow exceeds $50 \%$ of the time, the median Q50 value gives an average measure (Gordon et al. 2004). The Q90 or Q95 values are commonly used as low flow indices. The ratio of Q90/Q50 can be utilised as an index of base flow. Various techniques have been developed to isolate the base flow from the overall run-off hydrograph.

Hydrograph recession analysis is considered as one of the widely used techniques for separation of the base flow at a basin scale (Sujono et al. 2004). The main focus of the recession study is on the recession curve that is the falling limb of the hydrograph, which follows the stream crest when discharge reduces. Recession parts are chosen from the hydrographic value and can be separately or simultaneously analysed to obtain and understand the processes which impact dry-weather conditions. For a single hydrograph recession, a semi-logarithmic plot is originally applied for isolating a hydrograph into linear elements of river flow, interflow and dry-weather flow. When assessing a set of hydrograph recessions at a certain basin at the same time, a master recession curve is usually applied. Along with the graphical method, the fitting procedure also might be performed mathematically.

The base flow index (BFI) is the percentage of base flow to total flow estimated from a hydrograph separation approach. It was initially developed in a low flow analysis in the UK (Abebel and Foerch 2006) for describing the hydrological reaction of soils and geology of the basin. A high BFI value would expose the basin ability to feed flow of the stream during prolonged dry time periods. The BFI is associated with many characteristics of the river basin such as soil type and geology, topography, vegetation and climate (Tallaksen and van Lannen 2004; Longobardi and Villani 2008; Welderufael and Woyessa 2010; Price 2011). The index can change between 0.15 and 0.20 for an impervious basin to larger than 0.95 for a basin with a high storage volume and a steady flow system (WMO 2009).

\section{Representative case study region}

The Lower Zab River (also known as Little Zab River and Lesser Zab River) is one of the main tributaries of the Tigris River in the Erbil governorate in the north-east of Iraq. The river is situated with its tributaries between latitudes $36^{\circ} 50^{\prime} \mathrm{N}$ and $35^{\circ} 20^{\prime} \mathrm{N}$, and longitudes $43^{\circ} 25^{\prime} \mathrm{E}$ and $45^{\circ} 50^{\prime} \mathrm{E}$ (Saeedrashed and Guven 2013) as shown in Fig. 1. The current study examines the daily flow rate for the hydrological years between 1931 and 2013 at Dokan station, which is considered as a key hydrometric gauging station (Latitude $35^{\circ} 53^{\prime} 00^{\prime \prime} \mathrm{N}$ and Longitude $44^{\circ} 58^{\prime} 00^{\prime \prime} \mathrm{E}$ ). A vast majority of rivers have highly altered discharges as a result of water resources development and use; for example, the Lower Zab River has artificially relatively high flows during summer due to releases of water from the Dokan reservoir storage to supply irrigation and urban users.

\section{Rationale, aim, objectives and significance}

Particular activities that can affect dry-weather may contain river flow regulations, where river discharge is controlled through infrastructure elements such as dams, weirs or locks. Discharges from surface water storage structures 
Fig. 1 Overview of the Lower Zab River basin shapefile showing the Dokan hydrometric station location

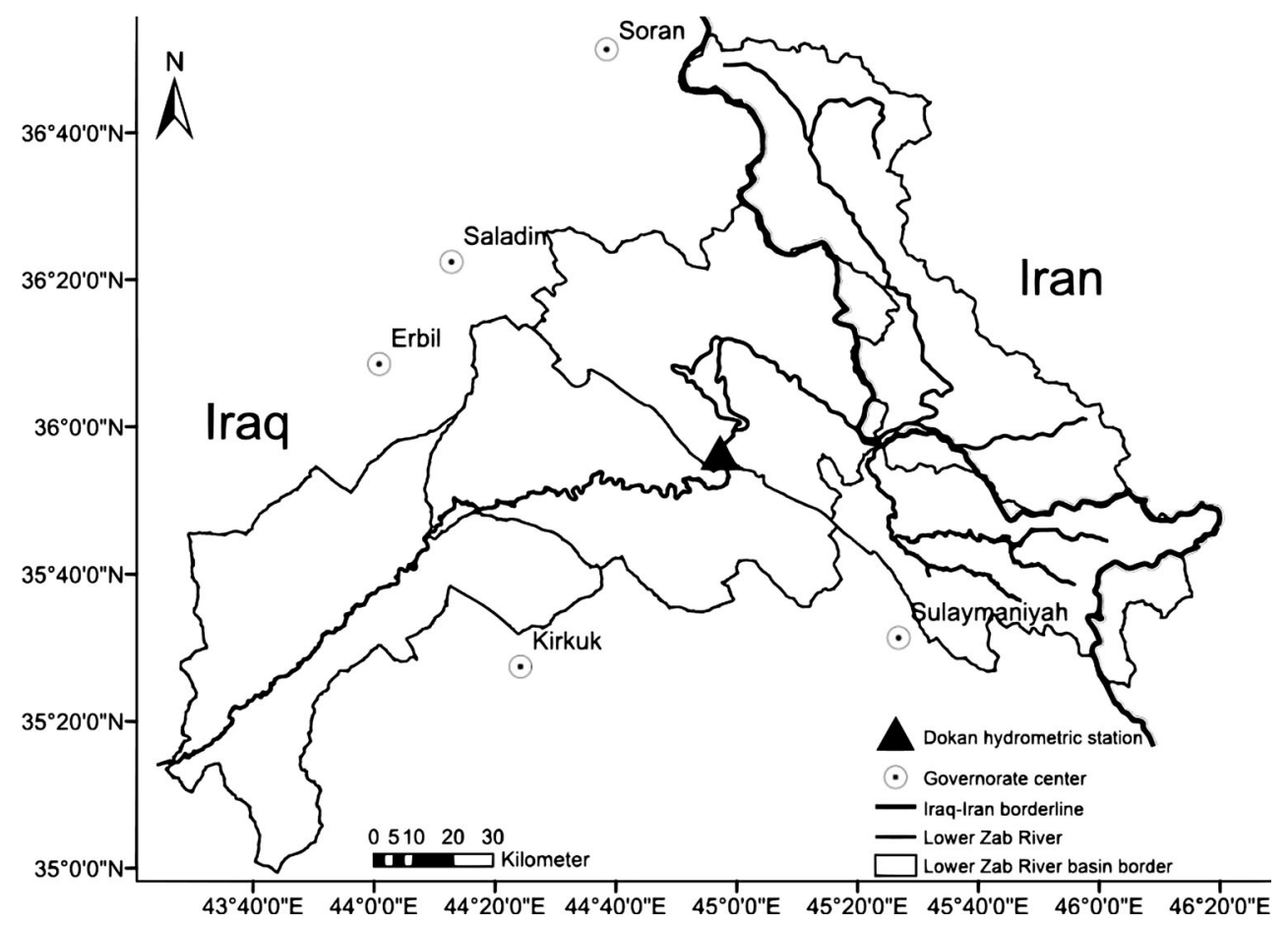

- To quantify the base flow contribution to the Lower Zab River (Fig. 1) flow as a function of time; and

- To evaluate the sensitivity of the groundwater contribution to river flows.

The flowchart visualised in Fig. 2 reveals how the above research objectives can be integrated to achieve the main research aim.

This study represents a critical step towards better understanding of the potential impact of river damming and streamflow alteration, climate change and drought events on groundwater contributions to river flow. The research outcomes will benefit engineers and decision makers in evaluating the contribution of groundwater at a basin scale.

\section{Methods}

The current research considers two recursive digital filtering algorithms coupled with the frequency duration function. The filtering algorithms are the one proposed by Eckhardt (2005) and a filtering algorithm by Chapman (1999). Both methods were utilised to isolate the dryweather flow of the upper Lower Zab River basin from the daily mean streamflow as recorded at the inlet of the Dokan reservoir (Latitude $35^{\circ} 53^{\prime} 00^{\prime \prime} \mathrm{N}$ and Longitude $\left.44^{\circ} 58^{\prime} 00^{\prime \prime} \mathrm{E}\right)$.

The Eckhardt (2005) method is applied to accomplish low pass filtering on the hydrograph to isolate the base flow, depending on Eq. (1): 
Fig. 2 New methodology for assessing the impacts of river damming as well as climate change and drought events on the groundwater contribution to river flow

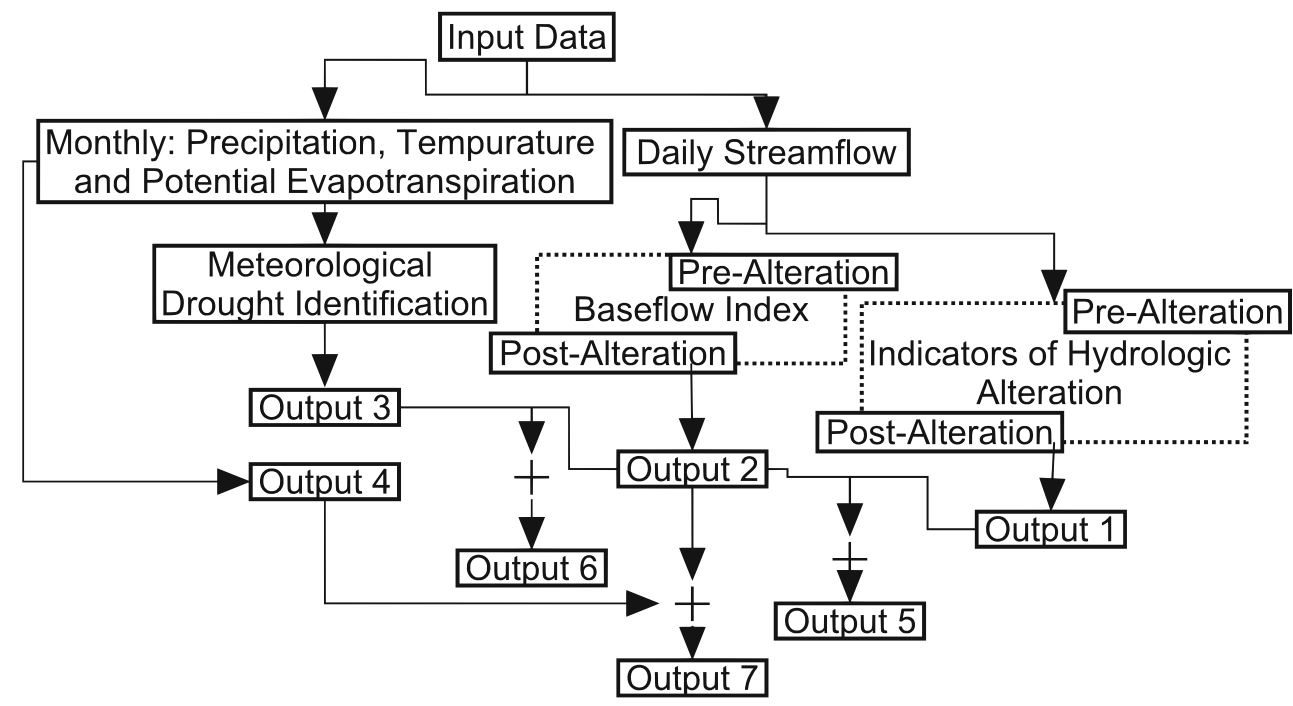

$\mathrm{BF}_{t}=\frac{\left(1-\mathrm{BFI}_{\max }\right) \times \alpha \times \mathrm{BF}_{t-1}+(1-\alpha) \times \mathrm{BFI}_{\max } \times \mathrm{TF}_{t}}{1-\alpha \times \mathrm{BFI}_{\max }}$

where $\mathrm{BF}\left(\mathrm{m}^{3} / \mathrm{s}\right)$ is the separated base flow, $\mathrm{BFI}_{\max }$ is the long-term percentage of dry-weather to total river flow, TF $\left(\mathrm{m}^{3} / \mathrm{s}\right)$ is the total streamflow, $\alpha$ is the filter parameter, and $t$ is the time step subject to $\mathrm{BF}_{t} \leq \mathrm{TF}_{t}$.

The Eckhardt recursive method needs to identify two parameters (Eckhardt 2005): (i) the recession constant $\alpha$, which can be resulted from recession curves statistical assessment of the hydrograph and (ii) the maximum amount of the base flow index $\mathrm{BFI}_{\max }$, which cannot be observed, but optimised based on the outcomes of other techniques. In this study, $\mathrm{BFI}_{\max }$ was considered to be 0.25 .

The second recursive digital filtering algorithm (Chapman 1999) is represented by Eq. (2):

$\mathrm{DF}_{t}=\frac{3 \times \alpha-1}{3-\alpha} \times \mathrm{TF}_{t-1}+\frac{2}{3-\alpha} \times\left(\mathrm{TF}_{t}-\mathrm{TF}_{t-1}\right)$

where $\mathrm{DF}_{t}\left(\mathrm{~m}^{3} / \mathrm{s}\right)$ is the direct run-off, $\mathrm{TF}\left(\mathrm{m}^{3} / \mathrm{s}\right)$ is the total streamflow, $\alpha$ is the filter parameter, and $t$ is the step of time.

However, the flow duration curve known as frequency duration curve is defined as a plot, which shows the ratio of time that a river discharge is possible to be equal or exceed some certain flow values. Such a curve depicts the catchment ability to provide flows of different values. The shape of the upper and lower areas of the plot is particularly important in assessing the channel and catchment attributes. The high flow region shape specifies the kind of flood system the catchment is expected to characterise, whilst the shape of the low flow area characterises the capacity of the catchment to endure dry seasons' low discharges.
The curve appearance is highly affected by a basic time unit that is used in drawing it. For example, when average daily discharges are used, then the resultant curve will be steep, whereas when a long period average flow such as a flow monthly mean is used, the resulting curve will be flat owing to averaging of short-term peaks with the intervening smaller flows during this month. Maximum values are progressively averaged out, as the period of time gets longer, e.g., for a flow duration curve depended on yearly discharges at a long record station.

To plot the flow duration curve, many steps have to be followed. Firstly, average daily discharges need to be sorted from the largest to the smallest number, involving a total of $n$ values. Secondly, each discharge value should be assigned a rank $M$, starting with 1 for the largest daily discharge value. Thirdly, the exceedance probability using Eq. (3) has to be calculated.

$P=\left(\frac{M}{n+1}\right) \times 100$

where $P$ is the probability that a specific discharge will be equal to or exceed a specific percentage of time; $M$ is the ranked (dimensionless) location on the listing; and $\mathrm{n}$ is the (dimensionless) figure of events for a period of the record.

Commonly, the Q50 is considered as the median discharge. A discharge $\geq \mathrm{Q} 50$ is interpreted as low flow. The ratio of Q90/Q50 represents a proportion of the streamflow contribution from groundwater aquifers or the corresponding ratio of the base flow element (Smakhtin 2001; Welderufael and Woyessa 2010; Stewart 2015).

Taking into consideration the generic methodology that has been suggested and utilised in this study, the results of the FDC analysis have been coupled with the Eckhardt algorithm to obtain the $\alpha$ value after taking $\mathrm{BFI}_{\max }=0.25$, which has been suggested by Eckhardt (2005) for perennial 
rivers with porous aquifers. Firstly, the long-term average yearly ratio of the total run-off from the dry-weather flow was determined after estimating the Q90 and Q50 values by using the flow duration curve analysis, coupling the Eckhardt recursive digital filtering algorithm with the flow duration curve. Based on $\alpha=0.925$ as a starting value (Arnold and Allen 1999; Smakhtin 2001), the daily river flow is filtered for different values of filter parameter $\alpha$ until the BFI is equal to the Q90/Q50 ratio. Various dryweather time series were obtained through using the filtered $\alpha$ value. After that, linear regression models were undertaken between the yearly BFI and the annual run-off for pre-regulated, post-regulated and integrated time periods to investigate the impact of river damming on the dryweather contribution.

\section{Results and discussion}

\section{Eckhardt integrated with flow duration curve}

Three time periods have been considered in the current research. Pre-river damming is considered as the first time period covering the water years from 1931 to 1965 . The post-river damming is the second studied time period that spans from 1966 to 2013, whereas the hydrological years 1931-2013 is the third time period, which is referred here as an integrated time period.

According to the outcome of the daily FDC at Dokan location for the pre- and post-river damming, the integrated time periods indicated that the Q90 and Q50 discharges were 35 and 101,31 and 100 , and 33 and $100 \mathrm{~m}^{3} / \mathrm{s}$, respectively. Accordingly, the BFI, which is the Q90/Q50 ratio, were nearly 35,31 , and $33 \%$, respectively, representing volumes of water that the river might be gaining from sub-surface flow or other delayed shallow groundwater sources regarding the studied periods.

This indicates that the BFI of the pre-regulated period was moderately greater than the values computed for both the postregulated and the integrated time periods. This can be attributed to the reduction in the groundwater involvement in the total Lower Zab River flow as a result of water being released from the reservoir during the dry period, which in turn reduces the BFI. Therefore, more consideration should be given to evaluate the aquifer characteristics and comprehend the aspects that might cause such alterations for improving managing of sub-surface resources within the basin.

\section{Impact assessment of river regulation on dry- weather separation}

For the pre-regulated time period between 1931 and 1965, and taking into consideration Eckhardt's digital filtering algorithm, outcomes reveal that the filter parameter $\alpha$ with a value of 0.982 produces a BFI that is the same as the one obtained from the FDC study. The yearly base flow volumes over this period fluctuate between 0.632 billion cubic meters $(\mathrm{bcm})$ recorded in 1958 and $2.826 \mathrm{bcm}$ observed in 1953. The corresponding yearly base flow depth varies between nearly 30 and $132 \mathrm{~mm}$ a year. The long-term yearly mean base flow volume and the matching standard deviation were 1.478 and $0.512 \mathrm{bcm}$ in this order (Figs. 3a, c).

Whereas the annual base flow magnitudes calculated by the Chapman algorithm over the same hydrological time periods varied between $1.38 \mathrm{bcm}$ recorded in 1958 and $5.71 \mathrm{bcm}$ observed in 1953 , the corresponding yearly base flow changed between approximately $65 \mathrm{~mm}$ a year and about $266 \mathrm{~mm}$ a year. The long-term yearly mean base flow storage and the corresponding standard deviation were 2.91 and 1.05 bcm, respectively (Figs. 3b, d).

Based on the established linear regression model expressed in Eqs. (4) and (5), Table 1 shows the linear regression models between the separated base flow and the total surface run-off for the two considered algorithms. Figure 3 reveals high coefficients of determination $\left(R^{2}\right)$ of 0.99 and 0.92 for the Eckhardt and the Chapman algorithms in this order.

For the post-regulated time period that spans from the hydrological years 1965-2013, and based on the outcome of the Eckhardt algorithm, the annual base flow magnitudes vary between $0.437 \mathrm{bcm}$ recorded in 2006 and $3.647 \mathrm{bcm}$ observed in 1968 . The matching yearly base flow changed from nearly $21 \mathrm{~mm}$ per year to nearly $170 \mathrm{~mm}$ per year. The long-term yearly mean base flow storage and the corresponding standard deviation were 1.45 and $0.70 \mathrm{bcm}$, respectively (Figs. 3a, c). However, the annual base flow magnitudes obtained from the Chapman algorithm varied from $0.871 \mathrm{bcm}$ observed in 2006 to $7.077 \mathrm{bcm}$ measured in 1968. The corresponding yearly base flow changed between about $40 \mathrm{~mm}$ per year to about $330 \mathrm{~mm}$ per year. The long-term yearly mean base flow volume and the conforming standard deviations were 2.88 and $1.31 \mathrm{bcm}$, respectively (Figs. 3b, d).

Additionally, a high $R^{2}$ of 0.99 was observed for the developed linear model Eq. (6). Table 1 indicates the association between the separated base flow and total flow for the two studied algorithms (Fig. 3e). Moreover, Fig. 3c and $d$ characterises the base flow, which is separated by the two considered filtering algorithms for the pre- and postdamming time periods. The obtained results indicate that the two studied recurrence filtering algorithms are strongly correlated. The $R^{2}=0.91$ and 0.99 for the base flow values obtained from the two algorithms. The created linear regression models are expressed in Eqs. (7) and (8) (Table 1). 

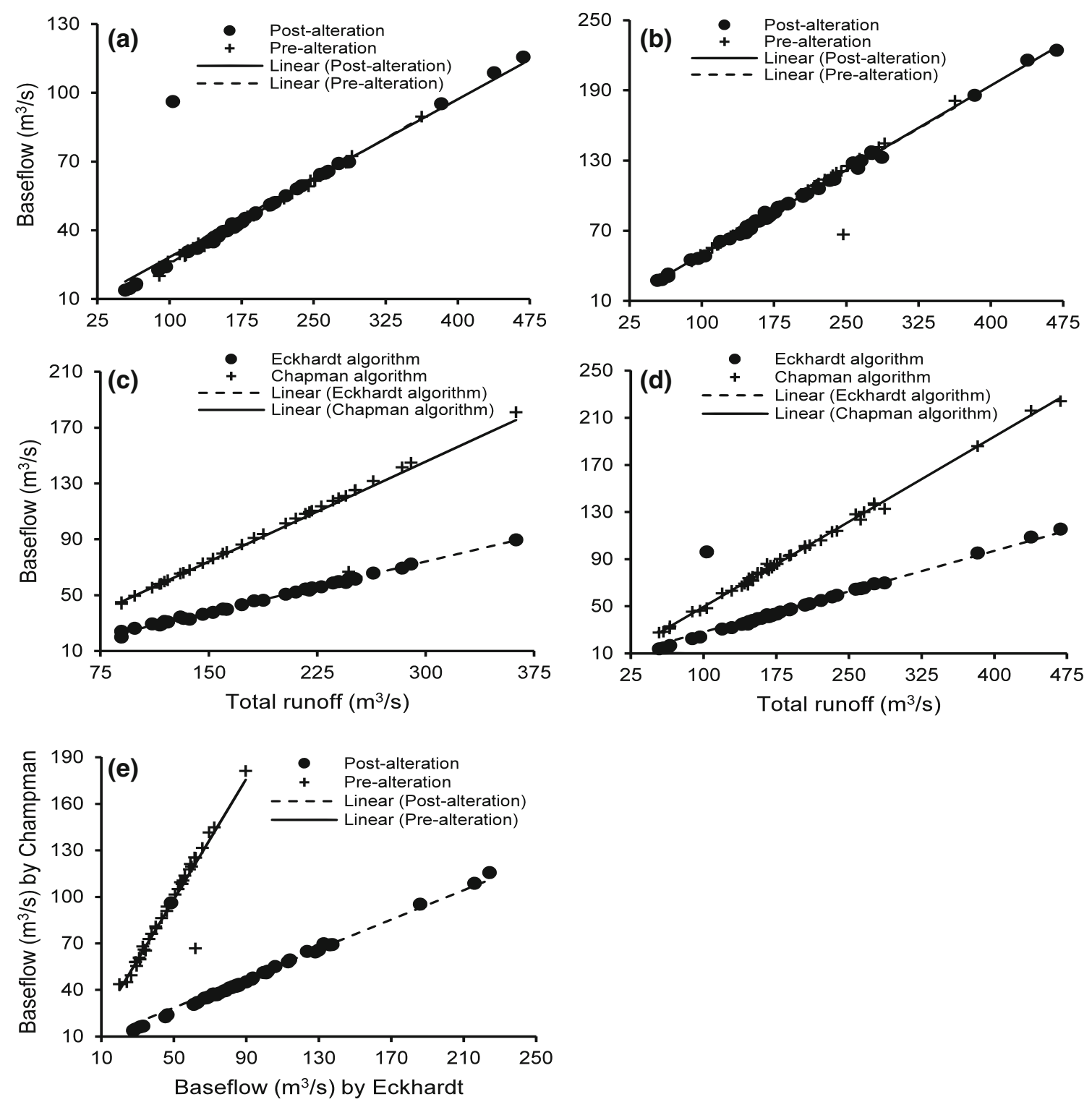

Fig. 3 The linear regression models for the relationships between the separated base flow and the total runoff a using the Eckhardt method; and $\mathbf{b}$ applying the Chapman recursive digital filtering algorithm for the

Furthermore, Fig. 4 shows the long-term variations of the total flow and the separated base flow volumes coupled with the BFI for the considered time periods. The derived base flows for all studied periods show almost similar patterns. However, a noticeable variation has been observed for the BFI for the post-alteration time period, which can be due to the water released from the river basin storage system.

\section{Assessment of base flow index linked to climate variability and drought phenomena}

The detection of the potential effects of climate variability on the meteorological and hydrological variables, and base time periods c pre-alteration; d post-alteration; and e the relationship between the two considered methods

flow index (BFI) over the upper part of the study area can be considered as a substantial step in the analysis of the impact of climate change on basin water resources availability. The main consequence of climate change is that wet and dry years are characterised by high and low flows in that order.

Yoo (2006) proposed that wet years are defined as periods in which the annual basin precipitation is more than the mean precipitation $\left(P_{\mathrm{av}}\right)+0.75 \times$ standard deviation (SD), whereas dry years are characterised by precipitation that is no more than the $P_{\mathrm{av}}-0.75 \times \mathrm{SD}$. Therefore, hydrological years with annual precipitation values between these two thresholds can be considered as normal years: $\quad P_{\mathrm{av}}-0.75 \times \mathrm{SD} \leq P \leq P_{\mathrm{av}}+0.75 \times \mathrm{SD} \quad($ Yang 


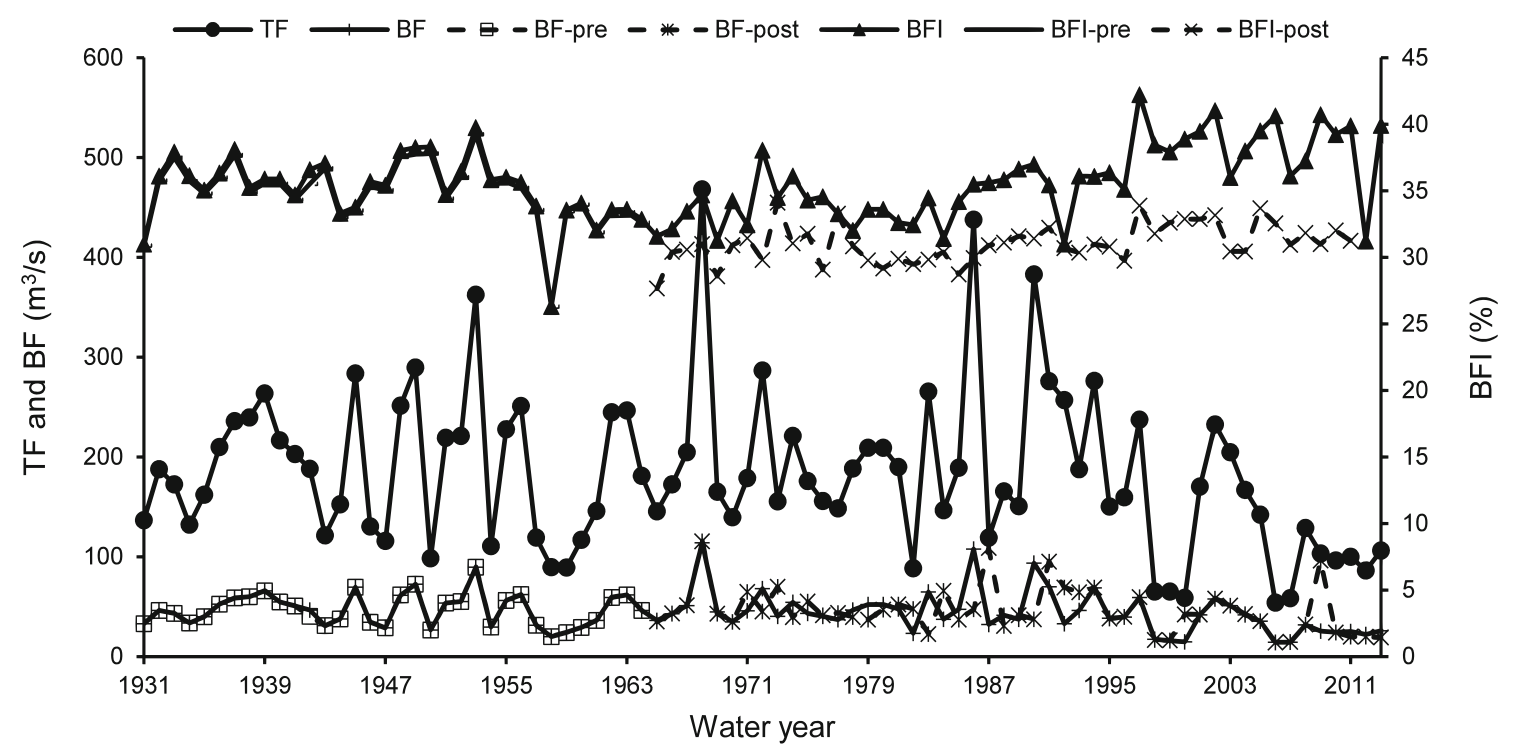

Fig. 4 Long-term monthly variation of total flow (TF), base flow (BF) and base flow index (BFI) at Dokan hydrometric station estimated by the Eckhardt filtering algorithm coupled with the flow duration curve (FDC) for the three studied time periods

Table 1 Developed linear regression models for the three considered time periods using both the Eckhardt algorithm linked to the flow duration curve and the Chapman digital algorithm

\begin{tabular}{lllll}
\hline Equation & & $R^{2}$ & Time period & Algorithm \\
\cline { 1 - 2 } No. & Formulation & & & \\
\hline 4 & $\mathrm{BF}^{\mathrm{a}}=0.482 \times \mathrm{TF}^{\mathrm{b}}+1.40$ & 0.99 & Pre-alteration & Eckhardt \\
5 & $\mathrm{BF}=0.476 \times \mathrm{TF}+2.74$ & 0.92 & & Chapman \\
6 & $\mathrm{BF}=0.482 \times \mathrm{TF}+1.40$ & 0.99 & Post-alteration & Eckhardt \\
7 & $\mathrm{BF}=0.23 \times \mathrm{BF}+5.24$ & 0.79 & & Chapman \\
8 & $\mathrm{BF}-\mathrm{Chapman}=0.51 \times \mathrm{BF}-$ Eckhardt -0.15 & 0.99 & & Eckhardt \\
9 & $\mathrm{BF}=0.24 \times \mathrm{TF}+1.24$ & 0.99 & Pre-alteration & \\
10 & $\mathrm{BF}=0.48 \times \mathrm{TF}+1.40$ & 0.99 & Post-alteration & \\
11 & $\mathrm{BF}=0.24 \times \mathrm{TF}+1.78$ & 0.97 & Integrated & Chapman \\
12 & $\mathrm{BF}=0.28 \times \mathrm{TF}+2.74$ & 0.92 & Pre-alteration & \\
13 & $\mathrm{BF}=0.48 \times \mathrm{TF}+1.40$ & 0.99 & Post-alteration & \\
14 & $\mathrm{BF}=0.24 \times \mathrm{TF}+1.78$ & 0.97 & Integrated & \\
\hline a & Base flow & & & \\
$\mathrm{b}$ & Total run-off & & &
\end{tabular}

et al. 2008). Figure 5 shows BFI time series for both wet and dry year thresholds.

Figure 5 also reveals that the water year 1987 witnessed a significant $(p<0.05)$ increase in the basin average precipitation of about $44 \%$ more than the normal water year maximum threshold. The considerable increase in the amount of precipitation results in a dramatic change in the river flow to about $118 \%$ (Fig. 6; Table 2), which in turn reduces the contribution of the groundwater to the total flow to the river. Whereas the complete opposite was noticed for the hydrological periods between 1998 and 2001, and between 2006 and 2008. These two periods witnessed a sharp decline in the basin average precipitation to about 40 and $60 \%$, respectively. The decrease of average precipitation led to a dramatic reduction in the Lower Zab River streamflow by approximately 66, 77 and $79 \%$ (corresponding annual mean flow volumes of $0.35 \times 10^{9} \mathrm{~m}^{3}$, $0.31 \times 10^{9} \mathrm{~m}^{3}$ and $\left.0.34 \times 10^{9} \mathrm{~m}^{3}\right)($ Table 3 ) for the water years 1998/1999, 1999/2000 and 2000/2001, which in turn increases the groundwater contribution, which is represented by the BFI. However, the hydrological years 2006/2007, 2007/2008 and 2008/2009 witnessed about 52, 80 and $83 \%$ streamflow reductions with corresponding $0.76 \times 10^{9} \mathrm{~m}^{3}, 0.29 \times 10^{9} \mathrm{~m}^{3}$ and $0.31 \times 10^{9} \mathrm{~m}^{3}$ annual 
Fig. 5 Long-term base flow index (BFI) with both wet and dry year thresholds coupled with long-term average precipitation for the time periods between 1979 and 2014

Fig. 6 Annual median anomaly of the Lower Zab River basin flows linked with the long-term base flow index (BFI) for the time period between 1966 and 2014

Fig. 7 Annual median anomaly of the Lower Zab River basin flows linked with the long-term base flow index (BFI) for the time period between 1966 and 2014. The reconnaissance drought index (RDI) coupled with the long-term base flow index (BFI) for the Lower Zab River basin between 1979 and 2014
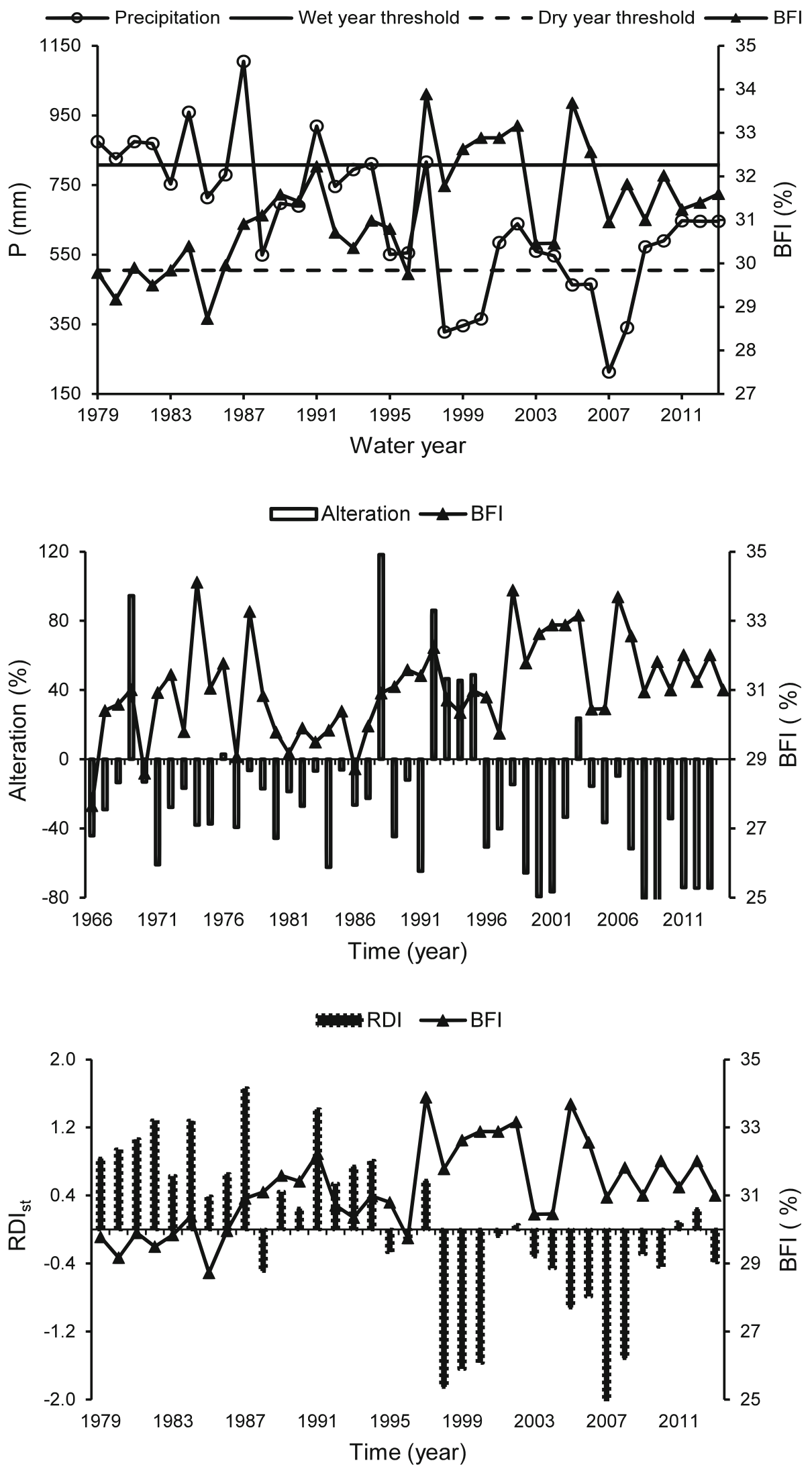
Table 2 Annual river flows, storage volumes, means of changed to unchanged storage ratios, and median anomalies between the periods $1979-1980$ and 1987-1988

\begin{tabular}{lllll}
\hline Water year & Flow $\left(\mathrm{m}^{3} / \mathrm{s}\right)$ & Storage $\left(\times 10^{9} \mathrm{~m}^{3}\right)$ & \multicolumn{2}{l}{ Percentage change } \\
\cline { 4 - 5 } & & & Long-term mean yearly storage & Anomaly \\
\hline $1979-1980$ & 148 & 4.68 & 0.79 & -46 \\
$1980-1981$ & 189 & 5.96 & 1.00 & -19 \\
$1981-1882$ & 210 & 6.61 & 1.11 & -27 \\
$1982-1983$ & 190 & 6.00 & 1.01 & -7 \\
$1983-1984$ & 88 & 2.79 & 0.47 & -62 \\
$1984-1985$ & 268 & 8.46 & 1.42 & -6 \\
$1985-1986$ & 148 & 4.66 & 0.78 & -26 \\
$1986-1987$ & 190 & 5.98 & 1.01 & -23 \\
$1987-1988$ & 436 & 13.75 & 2.31 & +118 \\
\hline
\end{tabular}

Table 3 Annual river flows, storages, means of changed to unchanged storage rations, and median anomalies between the period 1998-1999 and 2008-2009

\begin{tabular}{lllll}
\hline Water year & Flow $\left(\mathrm{m}^{3} / \mathrm{s}\right)$ & Storage $\left(\times 10^{9} \mathrm{~m}^{3}\right)$ & Percentage change \\
\cline { 5 - 5 } & & & Long-term mean yearly storage & Anomaly \\
\hline $1998-1999$ & 66 & 2.08 & 0.35 & -66 \\
$1999-2000$ & 65 & 2.04 & 0.34 & -79 \\
$2000-2001$ & 59 & 1.87 & 0.31 & -77 \\
$2001-2002$ & 171 & 5.40 & 0.91 & -34 \\
$2002-2003$ & 233 & 7.36 & 1.24 & +24 \\
$2003-2004$ & 205 & 6.46 & 1.09 & -15 \\
$2004-2005$ & 170 & 5.37 & 0.90 & -37 \\
$2005-2006$ & 170 & 5.38 & 0.90 & -10 \\
$2006-2007$ & 144 & 4.53 & 0.76 & -52 \\
$2007-2008$ & 54 & 1.70 & 0.29 & -80 \\
$2008-2009$ & 59 & 1.85 & 0.31 & -83 \\
\hline
\end{tabular}

Figure 8 shows that the basin potential to recharge the

mean flow volumes, respectively (Table 3). Furthermore, between 1991 and 2013, the natural flow regime witnessed a steep decline during which the flow alteration varied between -75 and $86 \%$ with corresponding $0.31 \times 10^{9} \mathrm{~m}^{3}$ and $1.24 \times 10^{9} \mathrm{~m}^{3}$ maximum and minimum annual mean storage volumes, respectively. Accordingly, the BFI increased from nearly 31 to almost $35 \%$.

Figure 7 presents the $\mathrm{RDI}_{\text {st }}$ values calculated for the case study region based on data from 1979 to 2014 in addition to long-term average BFI and indicates that a nonuniform cyclic pattern of drought and wet periods was observed for the study area concerning the studied time span. Noticeable droughts on a seasonal basis were observed for five years during the considered historical record, particularly for 1998/1999, 1999/2000, 2000/2001, 2007/2008 and 2008/2009 (average RDI values: -1.84 , $-1.67,-1.45,-2.91$ and -1.53 , respectively), which were also reported by many previous studies such as Fadhil (2011) and UNESCO (2014). Based on the observed drought phenomena over the study area, the groundwater contribution was increased dramatically from about $30-35 \%$.
Lower Zab River with water from aquifers started to increase dramatically from April until reaching the maximum value by the end of June, remaining constant until the middle of August and starting to decline slightly until the end of September. In addition, during the dry season, the BFI values revealed generally relatively high magnitudes of fluctuation, and they took relatively long time periods before reaching the peak point. Findings indicate that during the last few decades, climate change and drought phenomena have negatively affected the Lower Zab River storage water availability.

\section{Conclusions and recommendations}

The long-term mean annual BFI of the studied geographical region varied from 31,33 and $35 \%$ for the pre-alteration, post-alteration and integrated time periods, respectively. The obtained results suggest that 31,33 , and $35 \%$ of the long-term discharge in the Lower Zab River basin results from both the groundwater contribution and shallow sub-surface flow. The rather small variations in 
Fig. 8 Wet and dry seasonal variations of the base flow index (BFI) at Dokan hydrometric station estimated by the Eckhardt filtering algorithm coupled with the flow duration curve for the three studied time periods

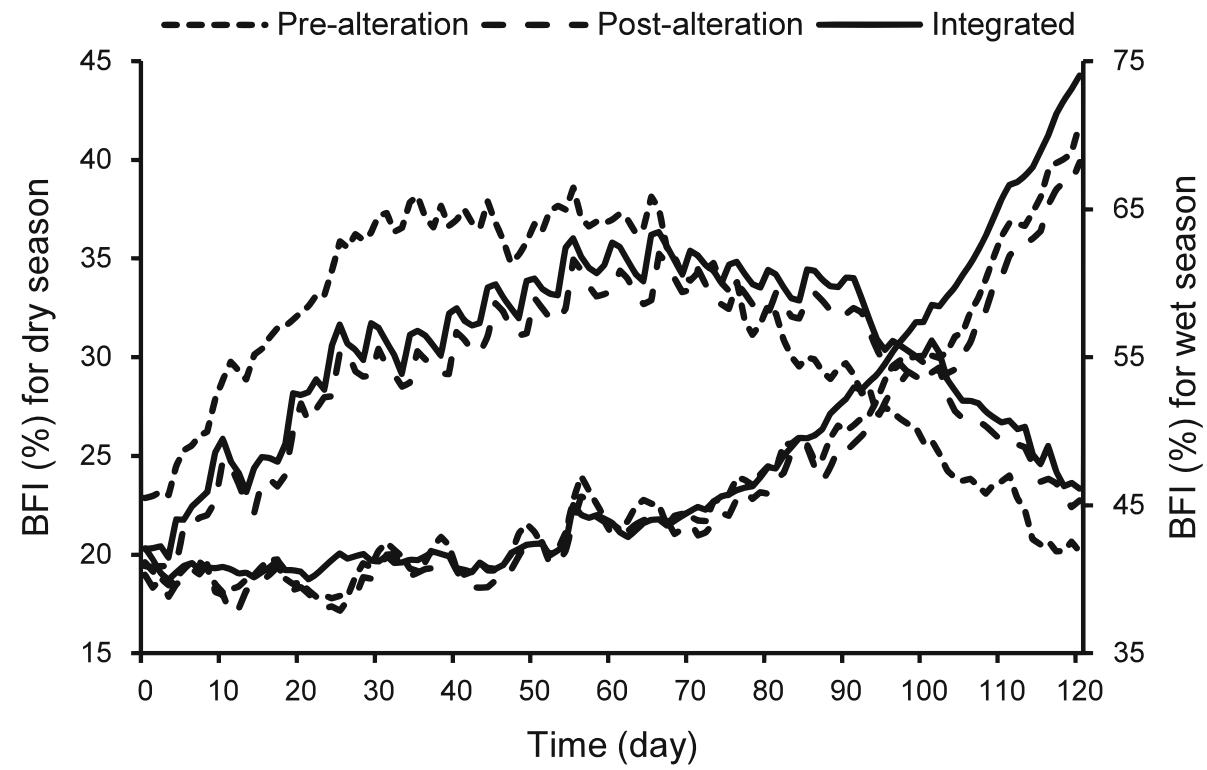

base flow contribution between the pre-alteration and the post-alteration time period resulted from water released from the reservoir during the dry period to cover the downstream water requirements. Therefore, more consideration must be given to the assessment of the characteristics of aquifers and understanding the factors that might lead to such variations. This could lead to improvements in the management of groundwater resources within the basin. This is because it is critical to investigate the base flow contribution to total discharge as a result of the pressing requirement for logical use of water resources and strong competition among several of the riparian nations. Furthermore, the proposed methodology can lead a better appreciation of the signature of the base flow and enlighten how the river damming, transformation and water utilisation in the upper part of the basin might alter the flow pattern of the base flow of the lower part of the basin.

The base flow index values increased in April and peaked by the end of June. A gradual decrease has been recorded between August and September. The water year 1987 witnessed a significant increase in the basin average precipitation of about $44 \%$ more than the normal water year maximum threshold. This resulted in a considerable change of the river flow to about $118 \%$ in addition to the reduction in the groundwater contribution to the total flow of the river. Furthermore, the water years for periods between 1998 and 2001 and 2006-2008 witnessed a sharp decline in the basin average precipitation to about 40 and $60 \%$, respectively. This led to a considerable reduction in the river flow by approximately 52 and $83 \%$, which in turn increased the groundwater contributions.

Seasonal droughts, which were observed during five years during the considered historical records (particularly for 1998/1999, 1999/2000, 2000/2001, 2007/2008 and $2008 / 2009$ corresponding average RDI values of -1.84 , $-1.67,-1.45,-2.91$ and -1.53 , respectively) resulted in a dramatic increase in terms of the corresponding groundwater contribution.

During the last few decades, there was a dramatic alteration in the river flow in particular during the non-rainy months. The variation might be attributed to the influence of both river damming and climate variability pressure in the upper part of the case study area, which in turn decreased the basin storage system availability from both surface and underground sources. Research findings imply that river alteration and climate variability should be considered for future stream basin managing strategies to escape the temporal disparity between strategy and such changes. Therefore, the proposed methodology is a rather practical and simple tool for the formulation of future river basin managing strategies, when difficult hydrological methods cannot be simulated through hydrological models, because of lack of measured data. Furthermore, the research should also be undertaken again for other regulated river basins located in different climatic zones to evaluate the impact of river damming and climate change on ground water contribution to streamflow.

Acknowledgements The research presented has been financially supported by the Iraqi Government. Thanks go to Furat Al-Faraj, Amjad Hussain and Al-Isawi Rawaa (all based at The University of Salford) for their kind help and support.

Open Access This article is distributed under the terms of the Creative Commons Attribution 4.0 International License (http://creative commons.org/licenses/by/4.0/), which permits unrestricted use, distribution, and reproduction in any medium, provided you give appropriate credit to the original author(s) and the source, provide a link to the Creative Commons license, and indicate if changes were made. 


\section{References}

Abebel A, Foerch G (2006) Catchment characteristics as predictors of dry-weather index (BFI) in Wabi Shebele river basin, East Africa. Paper presented at the Conference on International Agricultural Research for Development, Tropentag 2006, University of Bonn, Bonn. http://citeseerx.ist.psu.edu/viewdoc/ download?doi=10.1.1.112.3449\&rep=rep1\&type=pdf. Accessed 8 Feb 2016

Al-Faraj F, Scholz M (2014) Incorporation of the flow duration curve method within digital filtering algorithms to estimate the base flow contribution to total runoff. Water Resour Manag 28(15):5477-5489

Arnold JG, Allen PM (1999) Validation of automated methods for estimating baseflow and groundwater recharge from stream flow records. J Am Water Resour Assoc 35(2):411-424. doi:10.1111/ j.1752-1688.1999.tb03599.x

Arnold JG, Muttiah RS, Srinivasan R, Allen PM (2000) Regional estimation of base flow and groundwater recharge in the upper Mississippi river basin. J Hydrol 227(1-4):21-40. doi:10.1016/ S0022-1694(99)00139-0

Brodie RS, Hostetler S (2005) A review of techniques for analyzing base-flow from stream hydrographs. Proceedings of the NZHSIAH-NZSSS 2005 Conference, 28 November-2 December 2005, Auckland, New Zealand. http://data.daff.gov.au/data/warehouse/ brsShop/data/iah05_dry-weather_final.pdf. Accessed 8 Feb 2016

Chapman T (1999) A comparison of algorithms for streamflow recession and baseflow separation. Hydrol Process 13(5):701-714. doi:10.1002/(SICI)1099-1085(19990415)13: 5<701:AID-HYP774>3.0.CO;2-2

Cigizoglu HK, Bayazit M (2000) A generalized seasonal model for flow duration curve. Hydrol Process 14(6):1053-1067. doi:10. 1002/(SICI)1099-1085(20000430)14:6<1053:AID-HYP996>3. $0 . \mathrm{CO} ; 2-\mathrm{B}$

Eckhardt K (2005) How to construct recursive digital filters for base flow separation. Hydrol Process 19:507-515

Fadhil MA (2011) Drought mapping using geoinformation technology for some sites in the Iraqi Kurdistan region. Int J Digit Earth 4(3):239-257. doi:10.1080/17538947.2010.489971

Gordon NC, McMahon TA, Finlayson BL, Gippel CJ, Nathan RJ (2004) Stream hydrology: an introduction for ecologists, 2nd edn. Wiley, Chichester

Lim KJ, Engel BA, Tang Z, Choi J, Kim KS, Muthukrishnan S, Tripathy D (2005) Automated web GIS based hydrograph analysis tool, WHAT. J Am Water Res Assoc 41(6):1407-1416

Lim KJ, Parka YS, Kima J, Shina Y, Kimb NW, Kime SJ, Jeon JH, Engel BA (2010) Development of generic algorithm-based optimisation module in WHAT system for hydrograph analysis and model application. Comput Geosci 36(7):936-944. doi:10. 1016/j.cageo.2010.01.004

Linsley RK, Kohler MA, Paulhus JLH (1988) Hydrology for engineers. McGraw-Hill, London
Longobardi A, Villani P (2008) Dry-weather index regionalization analysis in a Mediterranean area and data scarcity context: role of the catchment permeability index. J Hydrol 355(1):63-75

Lu S, Wu B, Wei Y, Yan N, Wang H (2015) Quantifying impacts of climate variability and human activities on the hydrological system of the Haihe River Basin, China. Hydrol Earth Syst Sci 73:1491-1503

Nathan RJ, McMahon TA (1990) Evaluation of automated techniques for baseflow and recession analysis. Water Resour Res 26(7):1465-1473. doi:10.1029/WR026i007p01465

Price K (2011) Effects of watershed topography, soils, land use, and climate on base flow hydrology in humid regions: a review. Prog Phys Geogr 35(4):465-492. doi:10.1177/0309133311402714

Saeedrashed Y, Guven A (2013) Estimation of geomorphological parameters of Lower Zab River-Basin by using GIS-based remotely sensed image. Water Res Manag 27(1):209-219. doi:10.1007/s11269-012-0179-x

Smakhtin VU (2001) Low flow hydrology: a review. J Hydrol 240(3-4):147-186. doi:10.1016/S0022-1694(00)00340-1

Stewart MK (2015) Promising new baseflow separation and recession analysis methods applied to streamflow at Glendhu catchment, New Zealand. Hydrol Earth Syst Sci 19(6):2587-2603. doi:10. 5194/hess-19-2587-2015

Sujono J, Shikasho S, Hiramatsu K (2004) A comparison of techniques for hydrograph recession analysis. Hydrol Process 18(3):403-413. doi:10.1002/hyp.1247

Tallaksen LM, van Lanen HAJ (2004) Hydrological droughtprocesses and estimation methods for streamflow and groundwater. Developments in water sciences, vol 48. Elsevier, Amsterdam

UNESCO (2014) United Nations Educational, Scientific and Cultural Organization. Integrated drought risk management-DRM National framework for Iraq. An analysis report. http:// unesdoc.unesco.org/images/0022/002283/228343E.pdf UNESCWA and BGR (United Nations Economic and Social Commission for Western Asia; Bundesanstalt für Geowissenschaften und Rohstoffe) Inventory of shared water resources in Western Asia, Beirut

Welderufael W, Woyessa Y (2010) Stream flow analysis and comparison of methods for base flow separation: case study of the Modder River basin in central South Africa. Eur Water $8(2): 107-119$

WMO (2009) World Meteorological Organization. Manual of lowflow estimation and prediction, operational hydrology Report Number 50, World Meteorological Organization (WMO) Report Number 1029, WMO, Geneva

Yang T, Zhang Q, Xu C-Y, Chen X (2008) A spatial assessment of hydrologic alteration caused by dam construction in the middle and lower Yellow River, China. Hydrol Process 22(18):3829-3843. doi:10.1002/hyp.6993

Yoo C (2006) Long term analysis of wet and dry years in Seoul, Korea. J Hydrol 318(1-4):24-36 